\title{
Vaccine Design for CD8 T Lymphocyte Responses
}

\author{
Richard A. Koup and Daniel C. Douek \\ Immunology Laboratory, Vaccine Research Center, National Institute of Allergy and Infectious Diseases, \\ National Institutes of Health, Bethesda, Maryland 20892 \\ Correspondence: rkoup@mail.nih.gov
}

Vaccines are arguably the most powerful medical intervention in the fight against infectious diseases. The enormity of the global human immunodeficiency virus type 1 (HIV)/acquired immunodeficiency syndrome (AIDS) pandemic makes the development of an AIDS vaccine a scientific and humanitarian priority. Research on vaccines that induce T-cell immunity has dominated much of the recent development effort, mostly because of disappointing efforts to induce neutralizing antibodies through vaccination. Whereas T cells are known to limit HIV and other virus infections after infection, their role in protection against initial infection is much less clear. In this article, we will review the rationale behind a T-cell-based vaccine approach, provide an overview of the methods and platforms that are being applied, and discuss the impact of recent vaccine trial results on the future direction of T-cell vaccine research.

$\mathrm{O}$ ngoing efforts to develop effective vaccines against HIV are partly based on the principle that the specific antiviral CD8 T lymphocyte (CTL) response is crucial for immune control of viral replication. This certainly applies to many chronic persistent infections with viruses such as hepatitis $B$ virus ( $\mathrm{HBV})$, hepatitis $\mathrm{C}$ virus (HCV), cytomegalovirus (CMV), and EpsteinBarr virus (EBV). The same appears to be the case for HIV infection, with a substantial body of evidence suggesting that HIV-specific CD8 T-cell responses suppress HIV replication in vivo. Aside from the temporal association of an increase in CD8 T-cell responses with a decrease in viral load in acute infection (Borrow et al. 1994; Koup et al. 1994), the targeting of particular epitopes restricted by certain human leukocyte antigen (HLA) alleles, such as HLA$B^{*} 5701$, is consistently associated with low levels of virus load (Goulder and Watkins 2008; Hunt and Carrington 2008). In addition, CD8 T-cell depletion in simian immunodeficiency virus (SIV)-infected macaques is associated with an increase in viral load that is likely because of loss of SIV-specific T-cell responses (Jin et al. 1999; Schmitz et al. 1999). However, whereas the majority of T-cell-based vaccines tested in the macaque model have resulted in variably reduced viral load after SIV challenge (Shiver et al. 2002; Liu et al. 2009), the SIVspecific T-cell responses they elicit are insufficient in terms of frequency alone to define outcome (Casimiro et al. 2005; Moniuszko et al. 2005). Furthermore, it is not apparent

Editors: Frederic D. Bushman, Gary J. Nabel, and Ronald Swanstrom

Additional Perspectives on HIV available at www.perspectivesinmedicine.org

Copyright (C) 2011 Cold Spring Harbor Laboratory Press; all rights reserved; doi: 10.1101/cshperspect.a007252

Cite this article as Cold Spring Harb Perspect Med 2011;1:a007252 
R.A. Koup and D.C. Douek

what distinguishes the immunity afforded by a macaque CMV-based vaccine that profoundly controls SIV replication from those that merely blunt viral load (Hansen et al. 2009; Hansen et al. 2011). What is clear is that simple quantitative correlates of virus control have proved elusive (Ogg et al. 1998; Betts et al. 2001; Edwards et al. 2002; Addo et al. 2003), whereas qualitative aspects of the HIV-specific CD8 T-cell response seem to play a critical role in the efficacy of antiviral control (Betts et al. 2006).

\section{T-CELL CHARACTERISTICS ASSOCIATED WITH VIRUS CONTROL}

Qualitative aspects of immune control have generally been gleaned from observational studies in long-term nonprogressors, elite controllers, and HIV-2-infected nonprogressors, and have revealed a multitude of characteristics, which all appear to contribute to virus control (Fig. 1). First, it is likely that CD4 T cells will need to play an important role as effector cells per se, or in giving help to CD8 T cells (Rosenberg et al. 1997). Parenthetically, one should bear in mind that CD4 T-cell help is likely critical to the development of Env-specific high-affinity neutralizing antibodies. The phenotypes of $\mathrm{CD}^{+} \mathrm{T}$ cells that correlate with lower viral loads in chronic HIV infection are either central memory cells (Burgers et al. 2009) or effector memory cells (Hess et al. 2004; Addo et al. 2007) that do not express exhaustion markers such as PD-1 (Day et al. 2006; Petrovas et al. 2006; Trautmann et al. 2006). In terms of functional capacity, virus control has been associated with so-called polyfunctional CD8 T cells that secrete multiple cytokines (a property that is related to the sensitivity of antigen recognition) (Betts et al. 2006) as well as proliferative capacity (Day et al. 2007) and the ability to kill HIV-infected target cells (Yang et al. 1996; Migueles et al. 2008; Hersperger et al. 2010) or suppress HIV replication in vitro (Blackbourn et al. 1996; Yang et al. 1997; Spentzou et al. 2010). However, the qualitative properties of $\mathrm{CD}^{+} \mathrm{T}$-cell populations are also clearly impacted on by viral replication itself, thus rendering it difficult to disentangle cause from effect when interpreting associations between low viral load and particular phenotypic or functional profiles. Nevertheless, the rationale for what a T-cell-based vaccine should look like has been largely driven by data from individuals chronically infected with HIV.

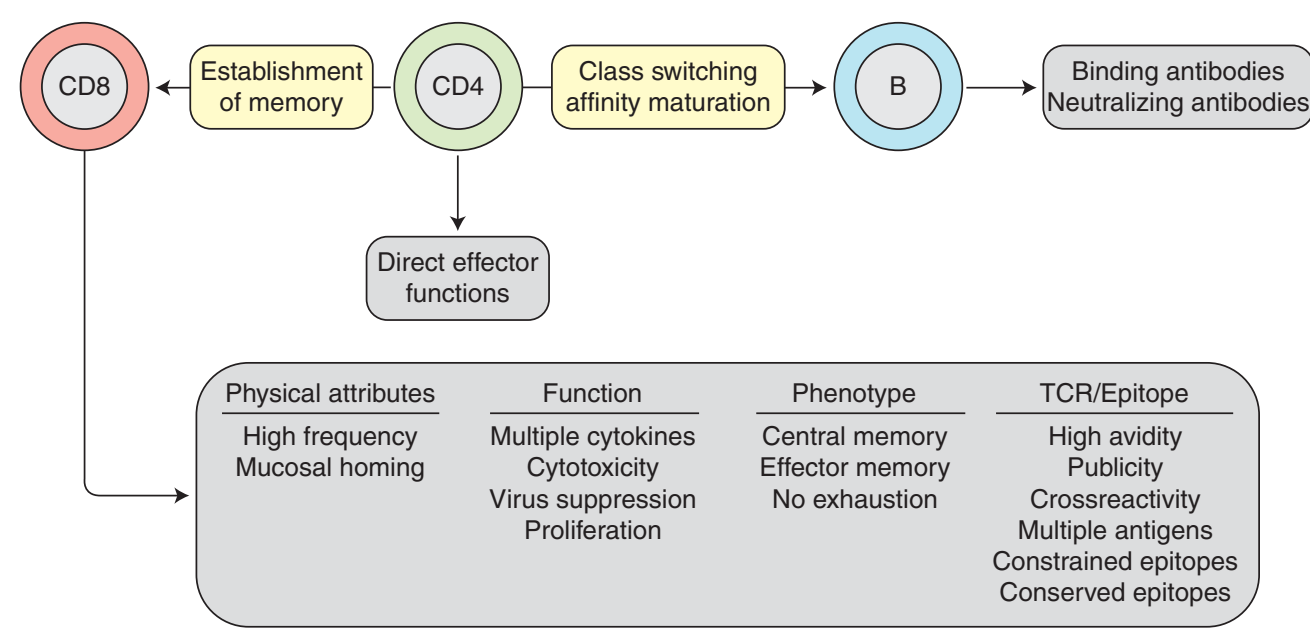

Figure 1. Attributes of CD8 T cells associated with virus control in infected individuals. These characteristics are thought important to emulate in the response elicited by a vaccine. The role of CD8 T cells should be viewed in the light of the roles of CD4 T cells and B cells. 
It should be noted that different vaccine modalities are available that can induce different patterns of CD4, CD8, and antibody responses (Table 1). Despite the availability of such an armamentarium with which to tailor the character of the vaccine-induced immune response, a pragmatic approach has dominated the $\mathrm{T}$-cell vaccine field, which has concentrated on vaccines to stimulate CD8 T cells. The origin of this bias is partially historical, and partially based on the general knowledge that CD8 T cells are efficient mediators of viral clearance, and would therefore be an appropriate component of a T-cell-based vaccine designed to lower viral load, if not clear HIV infection after challenge. It is for this reason that much of the subsequent discussion of actual vaccine approaches in this article will focus on methods that have been used to stimulate CD8, rather than CD4, T-cell responses through vaccination.

\section{DNA VACCINES}

Induction of major histocompatibility complex (MHC)-I-restricted CD8 T-cell responses is best accomplished when the vaccine antigen is produced endogenously in which presentation of peptides to major histocompatability class one molecules is more efficient than occurs via cross-presentation of exogenous proteins. In vivo injection of plasmid DNA is one of the most direct, although arguably not the most efficient, methods for accomplishing

Table 1. Vaccine modalities and the immunity that they elicit

\begin{tabular}{llll}
\hline & \multicolumn{2}{c}{ CD4 } & \multicolumn{2}{c}{ CD8 } & \\
Modality & T cells & T cells & Antibodies \\
\hline Whole killed HIV & +++ & - & +++ \\
Whole attenuated & ++ & ++ & ++ \\
$\quad$ HIV & & & \\
Live vector viruses & +++ & +++ & +++ \\
Live bacterial & +++ & + & +++ \\
$\quad$ vectors & & & \\
Pseudovirions & ++ & - & +++ \\
Replicons & ++ & ++ & ++ \\
DNA plasmids & ++ & + & + \\
Viral proteins & ++ & - & +++ \\
HIV peptides & ++ & ++ & - \\
\hline
\end{tabular}

endogenous expression of foreign proteins. Whereas early studies in mice demonstrated the potential of unmodified plasmid DNA as a vaccine modality (Fynan et al. 1993; Ulmer et al. 1993), early clinical trials in humans showed a general lack of potency of this approach, especially in stimulating class-Irestricted responses. This probably relates to the fact that after intramuscular injection, most DNA was being taken up and expressed by muscle cells, and that directing the uptake to professional antigen-presenting cells was required to improve immunogenicity (Wolff et al. 1990; Dupuis et al. 2000). Despite these early disappointing results, further refinements in the composition (promoter and codon use), manufacture, and purification (maintaining supercoiled structures) of plasmid DNA led to improvements in overall immunogenicity (Gao et al. 2003; Barouch et al. 2005; Pillai et al. 2008; Cai et al. 2009). Despite these improvements even the best preparations required several immunizations to achieve reasonable levels of immunity.

Multiple efforts have been made to further improve the immunogenicity of plasmid DNA. Among these have been attempts to improve delivery by use of needle-free delivery systems or incorporation of the DNA into various particle, metal, or lipid formulations in hopes of improving uptake into antigen-presenting cells (Klavinskis et al. 1997; Catanzaro et al. 2007; Helson et al. 2008). Although these approaches have been somewhat successful, another approach that has gained popularity lately is the application of pulsed electrical currents to the region of immunization, termed in vivo electroporation (Luxembourg et al. 2007). A number of devices have been developed and tested that differ in their degrees of complexity, ease of use, and comfort to the vaccinee. Generally the devices have been shown to improve the immunogenicity of plasmid DNA, and could help to make plasmid DNA a viable platform for routine vaccination, either by decreasing the number of inoculations or the dose of a vaccine that is required to generate protection. Because neither DNA nor these devices have yet been licensed, their development would 
likely require a combination license application to the Food and Drug Administration.

Another approach that has been tried to improve the immunogenicity of DNA vaccines is to include cytokines or chemokines (often termed molecular adjuvants), either in trans during or soon after the vaccination, or in cis by encoding for them within the plasmid DNA. The list of molecular adjuvants that have been evaluated include those designed to increase inflammation, skew the response toward Th1 or Th2, lead to proliferation of responding cells, attract appropriate $\mathrm{T}$ cells and anaphase-promoting complexes to the site of vaccination, or improve the induction of long-term memory (Abdulhaqq and Weiner 2008). Although some molecular adjuvants have shown a modest increase in the frequency of vaccine-induced $T$ cells, others have shown a profound effect (notably IL12 and IL15) especially when combined with electroporation (Chong et al. 2007; Hirao et al. 2008). In certain studies the responses induced in conjunction with molecular adjuvants were shown to improve aspects of protection against retroviral challenge; in some these were associated with improvements in T-cell responses whereas in others the impact appears to have been on aspects of the antibody response (Lai et al. 2007). A few of these approaches have been or are planned to be advanced into phase II trials.

Where DNA vaccines probably show the greatest promise is in prime-boost combination with other platforms. In the long history of DNA vaccine testing, it is generally accepted that DNA acts better as a prime than as a boost when combined with other modalities. This may be related to the observation that DNA immunization tends to stimulate a CD4-biased response, thereby providing the necessary T-cell help for an antibody response when proteins are used as the boost, or CD8 T-cell responses when viral vectors serve as the boost (Tritel et al. 2003). The only HIV vaccine currently in phase IIb testing is a DNA prime, recombinant adenovirus type 5 boost combination, and several other earlier phase trials use DNA as a prime for various different boosts. Even in primeboost combination, multiple immunizations with DNA are often required to achieve a maximum boost. In comparison, vector-vector or vector-protein combinations often require fewer immunizations to achieve adequate priming. One must therefore balance the impact of preexisting immunity and induction of vector-specific immune responses that are inherent to the use of a vector prime, to the possible increased number of vaccinations that may be required with DNA priming, when coming up with the optimum regimen for a given vaccine target. The lack of vector-specific immunity to DNA remains a compelling consideration when developing vaccines for worldwide distribution.

\section{VIRAL VECTORS}

Mass and targeted vaccination with vaccinia virus is responsible for the eradication of smallpox, making it arguably the most successful vaccine ever. Because of the extensive clinical experience with vaccinia, it is not surprising that this was one of the first viruses to be used in the development of recombinant vectors expressing foreign viral antigens as potential vaccine platforms. Indeed, the first documented HIV vaccine trial used a recombinant vaccinia virus expressing HIV genes (Zagury et al. 1988). In the subsequent 25 years, innumerable pox-based vectors expressing HIV antigens have been made and tested in human trials with mixed results (Pantaleo et al. 2010). Initial attempts used vaccinia, which is a live virus vaccine. This led to episodes of local and disseminated vaccinia infections and deaths when the vaccine was given (even in a presumably inactivated form) as immunotherapy to individuals already infected with HIV (Picard et al. 1991; Zagury 1991). The field then began to search for more attenuated pox viruses to use as vectors, and a number of alternatives were developed, including modified vaccinia ankara (MVA), fowlpox, ALVAC, and NyVac, most of which have been tested for efficacy in nonhuman primates, and for safety and immunogenicity in humans (Pantaleo et al. 2010). Not surprisingly, there is a general rule that with increasing attenuation comes decreasing 
immunogenicity, so by a standard measure of immunogenicity, these attenuated vectors tended to perform worse than parental vaccinia vectors, although with a possible increased margin of safety. Another characteristic of pox vectors is that unlike some viral vectors that express only the insert of choice, pox vectors have a large and complex genome and express many proteins in addition to the vaccine insert. As a result, the immunogenicity of the insert is often diluted by potentially more immunodominant responses directed to vector-specific antigens (Smith et al. 2005).

Despite these many potential pitfalls, a recent trial of an ALVAC-based vaccine in combination with protein boost showed moderate (31\%) efficacy against acquisition of HIV infection in a low-risk heterosexual cohort in Thailand (the RV144 trial, Table 2) (Rerks-Ngarm et al. 2009). That efficacy may have been higher in the first 6 months after full vaccination, but then waned over time. Of interest, virtually no CD8 T-cell responses were induced by this viral vector-based vaccine, and only CD4 T-cell and antibody responses appear to have been generated. Therefore, despite the use of a viral vector, the vaccine performed as would be expected of a protein-based vaccine. Intensive studies are ongoing to dissect any potential immune correlate of protection, but early indicators suggest it will not be a CD8 response.

Adenoviruses make up the majority of the other widely tested viral vectors (Lasaro and Ertl 2009). Adenovirus-based vaccines are easy to engineer, manufacture, and test. Adenovirus vectors can be made replication incompetent while expressing only the vaccine insert of interest, thereby alleviating the problems of safety and epitope competition that hamper pox-vector-based platforms. The fact that only the insert gene is expressed may be one factor responsible for the general ability of recombinant Ad vectors to stimulate high-frequency CD4 and CD8 T-cell responses. Levels of preexisting immunity vary among the five major serogroups of human adenoviruses, and can greatly influence the immunogenicity of the vector. The preexisting immunity that appears to be most important is the level of neutralizing antibody to the vector, as there is broad crossreactivity among $\mathrm{T}$-cell responses to the different serogroups. The impact of preexisting immunity can be at least partially alleviated by priming with either DNA or a low seroprevalent adenovirus.

Clinical trials of HIV vaccines based on adenovirus type 5 (rAd5) alone or in combination with DNA priming are ongoing (Table 2; Catanzaro et al. 2006; Koup et al. 2010). The rAd5 vaccine tested by Merck in the Step and Phambili trials contained HIV Gag, Pol, and Nef, but no Env, and therefore represents a true T-cell vaccine in that it stimulated neither virion binding nor neutralizing antibodies. Protection was intended to be afforded by stimulation of CD8 T-cell responses that would contain viral replication on infection, a contention supported by preclinical nonhuman primate testing (Shiver et al. 2002). Whereas the vaccine was shown to stimulate strong T-cell responses, the vaccine failed either to protect volunteers from acquisition of infection or to reduce viral loads after infection. In fact, there was an apparent increased risk of HIV infection in individuals with preexisting immunity to Ad5, raising the specter that Ad-specific CD4 T cells were being induced at the mucosa, thereby leading to enhanced risk of infection (Buchbinder

Table 2. Vaccines tested in human efficacy trials

\begin{tabular}{lllll}
\hline Product & \multicolumn{1}{c}{ Trial } & \multicolumn{1}{c}{ Antigens } & \multicolumn{1}{c}{ Immunity } & \multicolumn{1}{c}{ Population } \\
\hline VaxGen rgp120 & Vax003/Vax004 & Env & Ab, CD4 & MSM and IVDU \\
Merck rAd5 & Step/Phambili & Gag/Pol/Nef & CD8, CD4 & MSM \\
Sanofi Alvac/rgp120 & RV144 & Env + Gag & Ab, CD4 & General \\
VRC DNA/rAd5 & HVTN505 & Env/Gag/Pol/Nef & Ab, CD8, CD4 & MSM \\
\hline
\end{tabular}

MSM, men who have sex with men; IVDU, intravenous drug user. 
et al. 2008; McElrath et al. 2008). Subsequent analyses have failed to bear out this hypothesis. Efficacy testing of a vaccine developed at the Vaccine Research Center based on a DNA prime, rAd5 boost expressing HIV Gag, Pol, Nef, and Env is in progress (Koup et al. 2010). In addition, lower seroprevalent Ad-based vaccines are in preclinical testing in nonhuman primates and phase I testing in humans (Liu et al. 2009; Barouch 2010).

In addition to pox and Ad-based vectors, there is a long list of other viruses that have been tried as vaccine vectors with varying levels of success (Robert-Guroff 2007). These include adeno-associated virus (AAV), vesticular stomatitis virus (VSV), lymphocytic choriomeningitis virus (LCMV), herpes simplex virus (HSV), semliki forest virus (SFV), Venezuelan equine encephalitis virus (VEE), and others. Some of these have been tested for immunogenicity in humans, and have mostly proven to be less immunogenic than Ad-based platforms. Some are being reengineered to improve immunogenicity whereas others have been dropped from development. At this time it is difficult to predict which, if any, of these alternative vector designs may ultimately prove highly immunogenic and move forward in clinical development.

All of the viral vectors described so far are either replication incompetent or highly attenuated. However, some vaccine efforts are relying on the development of fully replicationcompetent viral vectors. The two most prominent in this class are replication-competent adenovirus and CMV. The goal with these approaches is to induce sustained effector memory $\mathrm{T}$-cell responses that may prove more effective at blocking or controlling HIV infection than the central memory responses that are induced by most replication-defective vectors (Peng et al. 2005). Of note is the fact that preclinical testing of a rhesus-based CMV vector in nonhuman primates has shown about $30 \%-50 \%$ efficacy in rapid and profound control of SIV infection in monkeys (Hansen et al. 2009, 2011). This efficacy is correlated with effector memory CD8 T cells and not with antibody responses. Although the exact mechanism of protection is far from defined in these studies, and a variety of safety issues still need to be addressed, the ability to achieve profound control of SIV infection in the absence of antibodies warrants further investigation and development of this platform.

\section{OTHER APPROACHES}

DNA and viral vectors offer the advantage of having the vaccine antigen expressed within the host cell, essentially assuring some antigen processing and MHC class I expression leading to the induction of CD8 T-cell responses. However, other vaccine strategies have been used to specifically target HIV antigens to MHC class I molecules. One way has been to combine soluble antigens with adjuvants that directly target and/or activate dendritic cells (DCs). There are many subsets of DCs, each with their own unique features and locations, but all of which are intimately involved in the stimulation of adaptive immune responses, and many of which have the unique capacity for efficient crosspresentation of soluble antigens to the class I pathway (Steinman 2008; Ueno et al. 2011). By understanding the location and expression of surface antigens and toll-like receptors (TLRs) on each subset, vaccine strategies can be tailored to stimulate the response of choice. Of importance in these strategies is an understanding of the movement of DCs after targeting by the vaccine antigen. Linkage of the antigen to the TLR ligand may be necessary because, once stimulated, DCs will migrate away from the depot of antigen to regional draining lymph nodes where $\mathrm{T}$-cell responses will be induced.

Many combinations of protein and TLR ligand have undergone preclinical testing with varying effects on CD4 and CD8 T-cell responses, and one DC targeting approach has advanced to a phase I clinical trial. This involves linking HIV Gag antigen to an antibody to DEC205 (a surface marker on DCs) combined with TLR stimulation of DCs using synthetic double-stranded RNA poly:IC (Cheong et al. 2010; Nchinda et al. 2010; Tewari et al. 2010). Even with the combination of DEC205 targeting and TLR stimulation of DCs, the majority of the T-cell response stimulated in response 
to the Gag antigen is mediated by CD4 rather than CD8 T cells. Avariety of other DC targeting strategies are undergoing preclinical evaluation.

Bacteria have also been proposed as vectors capable of stimulating CD8 T-cell responses. Among the candidates are bacteria that replicate inside monocytes or macrophages (listeria moncytogenes, Bacillus Calmette-Guerin [BCG] ) and those that are easily engineered to secrete proteins via the type III pathway (Salmonella, Shigella) (Garmory et al. 2003). Among these, BCG has the obvious advantage of a long history of use as a clinical vaccine in humans, and is certainly the furthest along in clinical development. Still, recombinant BCG and other mycobacterial vectors are probably still years away from clinical testing in humans.

Probably the simplest approach to inducing a class-I-restricted response is to vaccinate with peptides that can bind directly to class I molecules, thereby bypassing the need for intracellular processing and presentation. Different peptide preparations have been tested extensively, and various attempts have been made to improve the in vivo immunogenicity of this approach. Despite these efforts, standard vaccine delivery of peptides appears to have limited utility in stimulating CD8 T-cell responses, with the exception of one approach. Intravenous infusion of peripheral blood mononuclear cells coated ex vivo with peptides has shown great potency in preclinical animal studies (De Rose et al. 2008). Whether this approach will prove useful in human testing, especially considering the impracticality of such an approach for mass vaccination efforts, remains to be seen.

\section{ANTIGENS}

HIV expresses nine structural (Gag, Env) and nonstructural (Pol, Nef, Tat, Rev, Vpr, Vpu, Vif) proteins, some of which (Gag, Pol, Env) are further processed by viral or host proteases into more proteins. Several different criteria can be applied to decide which of these proteins to include in a T-cell-based vaccine: Sequence conservation, level of protein expression, and timing of protein expression are three obvious ones. The polymerase polyprotein (inclusive of protease, reverse transcriptase, and integrase) is certainly the most conserved across HIV strains and would therefore seem like a natural choice (Korber et al. 2007). The problem lies in the fact that these proteins are transcribed from a long Gag/Pol RNA through an inefficient frame shift mechanism, which leads to very low protein expression in infected cells. The efficiency with which CTL targeting these antigens can recognize and kill HIV-infected cells has therefore been called into question (Chen et al. 2009).

From the standpoint of the level of immune recognition, Gag and Env are the clear winners. Gag is reasonably well conserved across HIV strains, whereas Env has a mixture of highly conserved and highly variable regions, the latter being mostly the result of immune pressure from antibodies. In addition, both are structural proteins so they are expressed to high levels at the same time during the viral life cycle. The rest of the HIV proteins are produced from multiply spliced RNA species (Nef, Tat, Rev, Vpr, Vpu, Vif), are therefore expressed at lower levels than the structural proteins. Although these would therefore appear to be poor vaccine targets, the potential for low-level constitutive expression, or very early expression during the viral life cycle, has led to the inclusion of some of them within various $\mathrm{T}$-cell vaccines.

Some have evaluated T-cell responses during chronic infection as an indicator of which antigens to include in a vaccine. From a pure frequency standpoint, Gag, Pol, and Env are among the dominant responses, followed by Nef and then the other nonstructural proteins (Betts et al. 2001). This hierarchy may be somewhat different during acute infection (Goulder et al. 2001; Lichterfeld et al. 2004). As another strategy, some have assessed associations between CTL responses and HIV plasma RNA during chronic infection as an indicator of what antigens to include in a vaccine. When these types of evaluations are performed, it is clear that CTL responses to Gag are most strongly associated with virus control during chronic infection (Zuniga et al. 2006; Rolland et al. 2008). These types of analyses are probably measuring a complex combination of factors encompassing the efficiency of antiviral activity 
to an antigen and ease with which it can escape from that immune response (among other things). How this might predict protection in a prophylactic vaccine setting, in which the response would be present before virus infection, is not clear. In fact, at least one HIV antigen (Env) that ranks very poorly in this type of assessment was clearly the antigen that was responsible for protection in the only human trial of an HIV vaccine to show efficacy (RerksNgarm et al. 2009). One must therefore be careful when using data from chronic infections in deciding what antigens to include in a prophylactic vaccine.

Rather than relying on antigens known to be encoded by HIV, some are investigating unconventional antigens. It is known that there are cryptic start sites in the HIV genome that could lead to protein production from alternative reading frames. Recent evidence suggests that HIV-infected individuals and SIV-infected monkeys often make $\mathrm{T}$-cell responses to some of these cryptic epitopes, raising the question of whether they should or could be included in a vaccine (Bansal et al. 2010; Maness et al. 2010a,b). Even less conventional antigens have also been considered. Evidence suggests that transcriptional control of human endogenous retroviruses (HERV) is compromised in HIV infection, leading to protein production and the induction of T-cell responses to endogenous retroviral antigens (Garrison et al. 2007). Because these HERV proteins are very conserved, a vaccine approach based on expression of HERV antigens has been proposed.

\section{LOCATION}

The mucosal surfaces are not only the major route of transmission of HIV infection in both men and women but also the anatomical site of the greatest depletion of CD4 T cells during the course of the disease owing to the high availability of CCR ${ }^{+} \mathrm{CD} 4{ }^{+} \mathrm{T}$ cells for viral replication (Kotler et al. 1984; Guadalupe et al. 2003; Brenchley et al. 2004; Mehandru et al. 2004; Li et al. 2005; Mattapallil et al. 2005). The depletion of gastrointestinal CD4 T cells and the structural disruption of these mucosal surfaces are both massive and rapid, and therefore an effective HIV vaccine must interfere with virus replication during the narrow temporal window between the moment of mucosal transmission and the establishment of disseminated infection (Douek et al. 2006; Haase 2011). Recent data suggest that the majority of HIV infections among men who have sex with men and heterosexual HIV infections in women occur through a transmission event in which a single viral variant is responsible for establishing the initial disseminated infection (Keele et al. 2008; Abrahams et al. 2009; Haaland et al. 2009; Li et al. 2010). Thus, suppression of the initial transmission event is theoretically simple but the targeting of that suppression event presents a considerable problem of localization. This may require a high frequency of HIVspecific immunity in a very localized region, at the site of exposure, rather than systemic immunity. Although systemic immunization may elicit antigen-specific responses at mucosal surfaces (Belyakov et al. 1998; Baig et al. 2002; Pal et al. 2006) such approaches have not been overwhelmingly successful in significantly blocking or attenuating infection after mucosal challenge. However, the targeting of the mucosal surface itself with local immunization may elicit high-frequency local responses that can confer protection against mucosal virus challenge (Belyakov et al. 1998; Barnett et al. 2008). In this light, it is important to note that recent studies suggest that the ratio of SIVspecific CD8 T cells to SIV-infected CD4 T cells at the site of primary infection is critical in determining the degree of control of viral replication (Li et al. 2009). Thus, these data highlight a narrow window of opportunity when preexisting virus-specific memory $\mathrm{T}$-cell populations may endow the vaccinated host with a heightened ability to attenuate local virus replication at the mucosal surfaces.

\section{BREADTH, EPITOPE ESCAPE, AND THE IMPACT OF THE HOST RESPONSE}

In terms of the number of epitopes targeted, there is some debate over the optimal breadth of recognition that is required for virus control 
in vaccinated individuals. Studies from HIVinfected people in Africa and from vaccinated rhesus macaques suggest that the more epitopes targeted, in Gag rather than Env, the better (Zuniga et al. 2006; Kiepiela et al. 2007; Rolland et al. 2008). However, it would be clearly advantageous to target epitopes that are both conserved across different HIV subtypes (Goulder et al. 1996; Turnbull et al. 2006) and also sequence limited by viral fitness constraints (Martinez-Picado et al. 2006; Schneidewind et al. 2007). As mentioned above, the striking association between the expression of particular MHC alleles and virologic outcome speaks to a role for CD8 T cells in the control of viral replication (Kaslow et al. 1996; Hendel et al. 1999; Migueles et al. 2000; Gao et al. 2001), but the mechanisms underlying such protective effects remain poorly understood save for the presentation by particular MHC alleles of particular epitopes that are conserved owing to fitness constraints (Wang et al. 2009) and diversity in the T-cell receptor repertoire that targets such epitopes (Simons et al. 2008; Geldmacher et al. 2009). Although TCR diversity may seem an obvious advantage when targeting a virus that undergoes mutational epitope escape, studies in SIV-infected rhesus macaques have shown that the beneficial virologic outcome conferred by expression of the MHC allele Mamu $A^{*} 01$ may be mediated by the use of particular TCRs that target an immunodominant epitope (Price et al. 2009). Such TCRs are termed public because they are common to the epitope-specific response of more than one infected animal and as such represent an example of extreme bias in TCR usage.

However, the associations described above are far from clear-cut and still raise the question of whether responses of considerably greater magnitude than those elicited by current vaccine modalities would beneficially affect outcome. Furthermore, viral escape from the immune response by mutation presents a significant problem for any vaccine strategy. Indeed, studies in acute HIV infection suggest that CD8 T-cell responses to immunodominant epitopes are associated with control of viral replication but only during the acute phase. As the infected host enters the chronic phase, these epitopes are found to have escaped and the emerging HIV-specific CD8 T cells, which target a new set of epitopes, may not be as effective in the control of virus (Goulder et al. 2001; Leslie et al. 2004; Goonetilleke et al. 2009).

How does one increase the breadth of a vaccine to cover strain diversity? Historically this has been accomplished by including multiple strains of a virus in a vaccine. The seasonal influenza vaccine and polio vaccine are two classic examples. This approach is also being applied to HIV in which vaccines based on three or more strains of HIV are being tested. This approach clearly increases the likelihood that the $\mathrm{T}$-cell response will recognize more than one strain of HIV (Seaman et al. 2005), however, the cost and complexity of a vaccine increases significantly with each new strain that is added, and it is difficult to determine the impact of vaccine valency in actual protection in human clinical trials. HIV sequence alignments and knowledge of where T-cell epitopes reside within those alignments have been used to generate HIV antigens that encompass the most prevalent HIV strain sequences within just one or a few constructs. These approaches are based on linking sequences back to their common ancestor (center of tree approach), using consensus sequences, or creating mosaics of multiple strains in a single reading frame (Nickle et al. 2003; Mullins et al. 2004; Fischer et al. 2007). The latter approach (mosaic inserts) has progressed the furthest, both in terms of theoretical coverage (Fischer et al. 2007) and breadth of the $\mathrm{T}$-cell response generated in mouse and nonhuman primate testing (Kong et al. 2009; Barouch et al. 2010; Santra et al. 2010). Although these approaches increase the breadth of the T-cell response to a vaccine, their impact on breadth of protection across multiple strains remains to be determined.

\section{CONCLUDING REMARKS}

T-cell vaccine approaches to HIV have dominated much of the vaccine research agenda over the last decade. The enthusiasm for a $\mathrm{T}$-cell approach was driven by the inability to 
stimulate broad neutralizing antibodies through vaccination combined with a plethora of data from HIV-infected individuals indicating that CD8 $\mathrm{T}$ cells are instrumental in viral control. A vaccine representing a pure $\mathrm{T}$-cell approach (that is, one which contained no envelope antigen) underwent efficacy testing in humans and failed to protect from acquisition of infection (STEP Trial) (Buchbinder et al. 2008). More recently, the RV144 trial in Thailand showed a moderate efficacy of $31 \%$ protection from acquisition $(\mathrm{P}=0.04)$ with a vaccine that elicited envelope-specific antibodies and CD4 T cells but no CD8 T-cell responses (Rerks-Ngarm et al. 2009). Although these results may at first seem somewhat damning with respect to CD8 T-cell-based vaccines, many approaches remain to be tested. These newer modalities are designed to stimulate CD8 T cells, which differ in quality, quantity, phenotype, breadth, and location from the vaccines tested previously. Whether any of these approaches will prove beneficial remains to be seen.

It is important to look critically at the concept of a pure T-cell vaccine in the context of virus-specific adaptive immunity as a whole. The result of the RV144 trial suggests that the single-minded pursuit of solely eliciting CD8 $\mathrm{T}$ cells as the antiviral effectors may be of scientific interest, but may not be the best approach in practice. The combination of modalities that stimulate CD4 and CD8 T cells as well as antibodies, for which multiple approaches are available, appears to be the logical direction to follow. Indeed, it appears that the field is taking precisely this direction.

\section{ACKNOWLEDGMENTS}

The authors thank Dr. Barney Graham for his suggestions and helpful input.

\section{REFERENCES}

Abdulhaqq SA, Weiner DB. 2008. DNAvaccines: Developing new strategies to enhance immune responses. Immunol Res 42: 219-232.

Abrahams MR, Anderson JA, Giorgi EE, Seoighe C, Mlisana K, Ping LH, Athreya GS, Treurnicht FK, Keele BF, Wood N, et al. 2009. Quantitating the multiplicity of infection with human immunodeficiency virus type 1 subtype $C$ reveals a non-poisson distribution of transmitted variants. J Virol 83: 3556-3567.

Addo MM, Yu XG, Rathod A, Cohen D, Eldridge RL, Strick D, Johnston MN, Corcoran C, Wurcel AG, Fitzpatrick CA, et al. 2003. Comprehensive epitope analysis of human immunodeficiency virus type 1 (HIV-1)-specific T-cell responses directed against the entire expressed HIV-1 genome demonstrate broadly directed responses, but no correlation to viral load. J Virol 77: 2081-2092.

Addo MM, Draenert R, Rathod A, Verrill CL, Davis BT, Gandhi RT, Robbins GK, Basgoz NO, Stone DR, Cohen DE, et al. 2007. Fully differentiated HIV-1 specific $\mathrm{CD}^{+}{ }^{+} \mathrm{T}$ effector cells are more frequently detectable in controlled than in progressive HIV-1 infection. PLoS One 2: e321. doi: 10.1371/journal.pone.0000321.

Baig J, Levy DB, McKay PF, Schmitz JE, Santra S, Subbramanian RA, Kuroda MJ, Lifton MA, Gorgone DA, Wyatt LS, et al. 2002. Elicitation of simian immunodeficiency virus-specific cytotoxic T lymphocytes in mucosal compartments of rhesus monkeys by systemic vaccination. J Virol 76: 11484-11490.

Bansal A, Carlson J, Yan J, Akinsiku OT, Schaefer M, Sabbaj S, Bet A, Levy DN, Heath S, Tang J, et al. 2010. CD8 T cell response and evolutionary pressure to HIV-1 cryptic epitopes derived from antisense transcription. J Exp Med 207: 51-59.

Barnett SW, Srivastava IK, Kan E, Zhou F, Goodsell A, Cristillo AD, Ferrai MG, Weiss DE, Letvin NL, Montefiori D, et al. 2008. Protection of macaques against vaginal SHIV challenge by systemic or mucosal and systemic vaccinations with HIV-envelope. AIDS 22: 339-348.

Barouch DH. 2010. Novel adenovirus vector-based vaccines for HIV-1. Curr Opin HIVAIDS 5: 386-390.

Barouch DH, Yang ZY, Kong WP, Korioth-Schmitz B, Sumida SM, Truitt DM, Kishko MG, Arthur JC, Miura A, Mascola JR, et al. 2005. A human T-cell leukemia virus type 1 regulatory element enhances the immunogenicity of human immunodeficiency virus type 1 DNA vaccines in mice and nonhuman primates. J Virol 79: 8828-8834.

Barouch DH, O’Brien KL, Simmons NL, King SL, Abbink P, Maxfield LF, Sun YH, La Porte A, Riggs AM, Lynch DM, et al. 2010. Mosaic HIV-1 vaccines expand the breadth and depth of cellular immune responses in rhesus monkeys. Nat Med 16: 319-323.

Belyakov IM, Derby MA, Ahlers JD, Kelsall BL, Earl P, Moss B, Strober W, Berzofsky JA. 1998. Mucosal immunization with HIV-1 peptide vaccine induces mucosal and systemic cytotoxic $\mathrm{T}$ lymphocytes and protective immunity in mice against intrarectal recombinant HIV-vaccinia challenge. Proc Natl Acad Sci 95: 1709-1714.

Betts MR, Ambrozak DR, Douek DC, Bonhoeffer S, Brenchley JM, Casazza JP, Koup RA, Picker LJ. 2001. Analysis of total human immunodeficiency virus (HIV)-specific $\mathrm{CD}^{+}$and $\mathrm{CD}^{+}$T-cell responses: Relationship to viral load in untreated HIV infection. J Virol 75: 1198311991.

Betts MR, Nason MC, West SM, De Rosa SC, Migueles SA, Abraham J, Lederman MM, Benito JM, Goepfert PA, Connors M, et al. 2006. HIV nonprogressors preferentially maintain highly functional HIV-specific $\mathrm{CD}^{+} \mathrm{T}$ cells. Blood 107: 4781-4789. 
Blackbourn DJ, Mackewicz CE, Barker E, Hunt TK, Herndier B, Haase AT, Levy JA. 1996. Suppression of HIV replication by lymphoid tissue $\mathrm{CD} 8^{+}$cells correlates with the clinical state of HIV-infected individuals. Proc Natl Acad Sci 93: 13125-13130.

Borrow P, Lewicki H, Hahn BH, Shaw GM, Oldstone MB. 1994. Virus-specific $\mathrm{CD}^{+}$cytotoxic T-lymphocyte activity associated with control of viremia in primary human immunodeficiency virus type 1 infection. J Virol 68: 6103-6110.

Brenchley JM, Schacker TW, Ruff LE, Price DA, Taylor JH, Beilman GJ, Nguyen PL, Khoruts A, Larson M, Haase AT, et al. 2004. $\mathrm{CD}^{+} \mathrm{T}$ cell depletion during all stages of HIV disease occurs predominantly in the gastrointestinal tract. J Exp Med 200: 749-759.

Buchbinder SP, Mehrotra DV, Duerr A, Fitzgerald DW, Mogg R, Li D, Gilbert PB, Lama JR, Marmor M, Del Rio C, et al. 2008. Efficacy assessment of a cell-mediated immunity HIV-1 vaccine (the Step Study): A doubleblind, randomised, placebo-controlled, test-of-concept trial. Lancet 372: 1881-1893.

Burgers WA, Riou C, Mlotshwa M, Maenetje P, de Assis Rosa D, Brenchley J, Mlisana K, Douek DC, Koup R, Roederer M, et al. 2009. Association of HIV-specific and total $\mathrm{CD}^{+}{ }^{+}$memory phenotypes in subtype C HIV-1 infection with viral set point. J Immunol 182: 4751-4761.

Cai Y, Rodriguez S, Hebel H. 2009. DNA vaccine manufacture: scale and quality. Expert Rev Vaccines 8: 1277-1291.

Casimiro DR, Wang F, Schleif WA, Liang X, Zhang ZQ, Tobery TW, Davies ME, McDermott AB, O'Connor DH, Fridman A, et al. 2005. Attenuation of simian immunodeficiency virus SIVmac239 infection by prophylactic immunization with DNA and recombinant adenoviral vaccine vectors expressing Gag. J Virol 79: 15547-15555.

Catanzaro AT, Koup RA, Roederer M, Bailer RT, Enama ME, Moodie Z, Gu L, Martin JE, Novik L, Chakrabarti BK, et al. 2006. Phase 1 safety and immunogenicity evaluation of a multiclade HIV-1 candidate vaccine delivered by a replication-defective recombinant adenovirus vector. J Infect Dis 194: 1638-1649.

Catanzaro AT, Roederer M, Koup RA, Bailer RT, Enama ME, Nason MC, Martin JE, Rucker S, Andrews CA, Gomez PL, et al. 2007. Phase I clinical evaluation of a six-plasmid multiclade HIV-1 DNA candidate vaccine. Vaccine 25: 4085-4092.

Chen H, Piechocka-Trocha A, Miura T, Brockman MA, Julg BD, Baker BM, Rothchild AC, Block BL, Schneidewind A, Koibuchi T, et al. 2009. Differential neutralization of human immunodeficiency virus (HIV) replication in autologous CD4 T cells by HIV-specific cytotoxic T lymphocytes. J Virol 83: 3138-3149.

Cheong C, Choi JH, Vitale L, He LZ, Trumpfheller C, Bozzacco L, Do Y, Nchinda G, Park SH, Dandamudi DB, et al. 2010. Improved cellular and humoral immune responses in vivo following targeting of HIV Gag to dendritic cells within human anti-human DEC205 monoclonal antibody. Blood 116: 3828-3838.

Chong SY, Egan MA, Kutzler MA, Megati S, Masood A, Roopchard V, Garcia-Hand D, Montefiori DC, Quiroz J, Rosati M, et al. 2007. Comparative ability of plasmid IL-12 and IL-15 to enhance cellular and humoral immune responses elicited by a SIVgag plasmid DNAvaccine and alter disease progression following $\operatorname{SHIV}(89.6 \mathrm{P})$ challenge in rhesus macaques. Vaccine 25: 4967-4982.

Day CL, Kaufmann DE, Kiepiela P, Brown JA, Moodley ES, Reddy S, Mackey EW, Miller JD, Leslie AJ, DePierres C, et al. 2006. PD-1 expression on HIV-specific T cells is associated with T-cell exhaustion and disease progression. Nature 443: 350-354.

Day CL, Kiepiela P, Leslie AJ, van der Stok M, Nair K, Ismail N, Honeyborne I, Crawford H, Coovadia HM, Goulder PJ, et al. 2007. Proliferative capacity of epitope-specific CD8 T-cell responses is inversely related to viral load in chronic human immunodeficiency virus type 1 infection. J Virol 81: 434-438.

De Rose R, Fernandez CS, Smith MZ, Batten CJ, Alcantara S, Peut V, Rollman E, Loh L, Mason RD, Wilson K, et al. 2008. Control of viremia and prevention of AIDS following immunotherapy of SIV-infected macaques with peptide-pulsed blood. PLoS Pathog 4: e1000055.

Douek DC, Kwong PD, Nabel GJ. 2006. The rational design of an AIDS vaccine. Cell 124: 677-681.

Dupuis M, Denis-Mize K, Woo C, Goldbeck C, Selby MJ, Chen M, Otten GR, Ulmer JB, Donnelly JJ, Ott G, et al. 2000. Distribution of DNA vaccines determines their immunogenicity after intramuscular injection in mice. J Immunol 165: 2850-2858.

Edwards BH, Bansal A, Sabbaj S, Bakari J, Mulligan MJ, Goepfert PA. 2002. Magnitude of functional CD8 ${ }^{+}$ T-cell responses to the gag protein of human immunodeficiency virus type 1 correlates inversely with viral load in plasma. J Virol 76: 2298-2305.

Fischer W, Perkins S, Theiler J, Bhattacharya T, Yusim K, Funkhouser R, Kuiken C, Haynes B, Letvin NL, Walker BD, et al. 2007. Polyvalent vaccines for optimal coverage of potential T-cell epitopes in global HIV-1 variants. Nat Med 13: 100-106.

Fynan EF, Webster RG, Fuller DH, Haynes JR, Santoro JC, Robinson HL. 1993. DNA vaccines: Protective immunizations by parenteral, mucosal, and gene-gun inoculations. Proc Natl Acad Sci 90: 11478-11482.

Gao X, Nelson GW, Karacki P, Martin MP, Phair J, Kaslow R, Goedert JJ, Buchbinder S, Hoots K, Vlahov D, et al. 2001 Effect of a single amino acid change in MHC class I molecules on the rate of progression to AIDS. $N$ Engl J Med 344: 1668-1675.

Gao F, Li Y, Decker JM, Peyerl FW, Bibollet-Ruche F, Rodenburg CM, Chen Y, Shaw DR, Allen S, Musonda R, et al. 2003. Codon usage optimization of HIV type 1 subtype $\mathrm{C}$ gag, pol, env, and nef genes: In vitro expression and immune responses in DNA-vaccinated mice. AIDS Res Hum Retroviruses 19: 817-823.

Garmory HS, Leary SE, Griffin KF, Williamson ED, Brown KA, Titball RW. 2003. The use of live attenuated bacteria as a delivery system for heterologous antigens. J Drug Target 11: 471-479.

Garrison KE, Jones RB, Meiklejohn DA, Anwar N, Ndhlovu LC, Chapman JM, Erickson AL, Agrawal A, Spotts G, Hecht FM, et al. 2007. T cell responses to human endogenous retroviruses in HIV-1 infection. PLoS Pathog 3: e165.

Geldmacher C, Metzler IS, Tovanabutra S, Asher TE, Gostick E, Ambrozak DR, Petrovas C, Schuetz A, 
R.A. Koup and D.C. Douek

Ngwenyama N, Kijak G, et al. 2009. Minor viral and host genetic polymorphisms can dramatically impact the biologic outcome of an epitope-specific CD8 T-cell response. Blood 114: 1553-1562.

Goonetilleke N, Liu MK, Salazar-Gonzalez JF, Ferrari G, Giorgi E, Ganusov VV, Keele BF, Learn GH, Turnbull EL, Salazar MG, et al. 2009. The first T cell response to transmitted/founder virus contributes to the control of acute viremia in HIV-1 infection. J Exp Med 206: $1253-1272$.

Goulder PJ, Watkins DI. 2008. Impact of MHC class I diversity on immune control of immunodeficiency virus replication. Nat Rev Immunol 8: 619-630.

Goulder PJ, Bunce M, Krausa P, McIntyre K, Crowley S, Morgan B, Edwards A, Giangrande P, Phillips RE, McMichael AJ. 1996. Novel, cross-restricted, conserved, and immunodominant cytotoxic $\mathrm{T}$ lymphocyte epitopes in slow progressors in HIV type 1 infection. AIDS Res Hum Retroviruses 12: 1691-1698.

Goulder PJ, Altfeld MA, Rosenberg ES, Nguyen T, Tang Y, Eldridge RL, Addo MM, He S, Mukherjee JS, Phillips MN, et al. 2001. Substantial differences in specificity of HIV-specific cytotoxic T cells in acute and chronic HIV infection. J Exp Med 193: 181-194.

Guadalupe M, Reay E, Sankaran S, Prindiville T, Flamm J, McNeil A, Dandekar S. 2003. Severe CD4 ${ }^{+}$T-cell depletion in gut lymphoid tissue during primary human immunodeficiency virus type 1 infection and substantial delay in restoration following highly active antiretroviral therapy. J Virol 77: 11708-11717.

Haaland RE, Hawkins PA, Salazar-Gonzalez J, Johnson A, Tichacek A, Karita E, Manigart O, Mulenga J, Keele BF, Shaw GM, et al. 2009. Inflammatory genital infections mitigate a severe genetic bottleneck in heterosexual transmission of subtype A and C HIV-1. PLoS Pathog 5: e1000274.

Haase AT. 2011. Early events in sexual transmission of HIV and SIV and opportunities for interventions. Annu Rev Med 62: 127-139.

Hansen SG, Vieville C, Whizin N, Coyne-Johnson L, Siess DC, Drummond DD, Legasse AW, Axthelm MK, Oswald K, Trubey CM, et al. 2009. Effector memory T cell responses are associated with protection of rhesus monkeys from mucosal simian immunodeficiency virus challenge. Nat Med 15: 293-299.

Hansen SG, Ford JC, Lewis MS, Ventura AB, Hughes CM, Coyne-Johnson L, Whizin N, Oswald K, Shoemaker R, Swanson T, et al. 2011. Profound early control of highly pathogenic SIV by an effector memory T-cell vaccine. Nature 473: 523-527.

Helson R, Olszewska W, Singh M, Megede JZ, Melero JA, O'Hagan D, Openshaw PJ. 2008. Polylactide-co-glycolide (PLG) microparticles modify the immune response to DNA vaccination. Vaccine 26: 753-761.

Hendel H, Caillat-Zucman S, Lebuanec H, Carrington M, O'Brien S, Andrieu JM, Schachter F, Zagury D, Rappaport J, Winkler C, et al. 1999. New class I and II HLA alleles strongly associated with opposite patterns of progression to AIDS. J Immunol 162: 6942-6946.

Hersperger AR, Pereyra F, Nason M, Demers K, Sheth P, Shin LY, Kovacs CM, Rodriguez B, Sieg SF, Teixeira-Johnson L, et al. 2010. Perforin expression directly ex vivo by
HIV-specific CD8 T-cells is a correlate of HIV elite control. PLoS Pathog 6: e1000917.

Hess C, Altfeld M, Thomas SY, Addo MM, Rosenberg ES, Allen TM, Draenert R, Eldrige RL, van Lunzen J, Stellbrink HJ, et al. 2004. HIV-1 specific CD8 ${ }^{+}$T cells with an effector phenotype and control of viral replication. Lancet 363: 863-866.

Hirao LA, Wu L, Khan AS, Hokey DA, Yan J, Dai A, Betts MR, Draghia-Akli R, Weiner DB. 2008. Combined effects of IL-12 and electroporation enhances the potency of DNA vaccination in macaques. Vaccine 26: 3112-3120.

Hunt PW, Carrington M. 2008. Host genetic determinants of HIV pathogenesis: An immunologic perspective. Curr Opin HIVAIDS 3: 342-348.

Jin X, Bauer DE, Tuttleton SE, Lewin S, Gettie A, Blanchard J, Irwin CE, Safrit JT, Mittler J, Weinberger L, et al. 1999. Dramatic rise in plasma viremia after $\mathrm{CD} 8^{+} \mathrm{T}$ cell depletion in simian immunodeficiency virus-infected macaques. J Exp Med 189: 991-998.

Kaslow RA, Carrington M, Apple R, Park L, Munoz A, Saah AJ, Goedert JJ, Winkler C, O'Brien SJ, Rinaldo C, et al. 1996. Influence of combinations of human major histocompatibility complex genes on the course of HIV-1 infection. Nat Med 2: 405-411.

Keele BF, Giorgi EE, Salazar-Gonzalez JF, Decker JM, Pham KT, Salazar MG, Sun C, Grayson T, Wang S, Li H, et al. 2008. Identification and characterization of transmitted and early founder virus envelopes in primary HIV-1 infection. Proc Natl Acad Sci 105: 7552-7557.

Kiepiela P, Ngumbela K, Thobakgale C, Ramduth D, Honeyborne I, Moodley E, Reddy S, de Pierres C, Mncube Z, Mkhwanazi N, et al. 2007. CD8 ${ }^{+}$T-cell responses to different HIV proteins have discordant associations with viral load. Nat Med 13: 46-53.

Klavinskis LS, Gao L, Barnfield C, Lehner T, Parker S. 1997. Mucosal immunization with DNA-liposome complexes. Vaccine 15: 818-820.

Kong WP, Wu L, Wallstrom TC, Fischer W, Yang ZY, Ko SY, Letvin NL, Haynes BF, Hahn BH, Korber B, et al. 2009. Expanded breadth of the T-cell response to mosaic human immunodeficiency virus type 1 envelope DNA vaccination. J Virol 83: 2201-2215.

Korber BTM, Brander C, Haynes BF, Koup RA, Moore JP, Walker BD, Watkins DI, ed. 2007. HIV molecular immunology. Los Alamos National Laboratory, Los Alamos, NM.

Kotler DP, Gaetz HP, Lange M, Klein EB, Holt PR. 1984. Enteropathy associated with the acquired immunodeficiency syndrome. Ann Intern Med 101: 421-428.

Koup RA, Safrit JT, Cao Y, Andrews CA, McLeod G, Borkowsky W, Farthing C, Ho DD. 1994. Temporal association of cellular immune responses with the initial control of viremia in primary human immunodeficiency virus type 1 syndrome. J Virol 68: 4650-4655.

Koup RA, Roederer M, Lamoreaux L, Fischer J, Novik L, Nason MC, Larkin BD, Enama ME, Ledgerwood JE, Bailer RT, et al. 2010. Priming immunization with DNA augments immunogenicity of recombinant adenoviral vectors for both HIV-1 specific antibody and T-cell responses. PLoS One 5: e9015.

Lai L, Vodros D, Kozlowski PA, Montefiori DC, Wilson RL, Akerstrom VL, Chennareddi L, Yu T, Kannanganat S, 
Ofielu L, et al. 2007. GM-CSF DNA: An adjuvant for higher avidity IgG, rectal IgA, and increased protection against the acute phase of a SHIV-89.6P challenge by a DNA/MVA immunodeficiency virus vaccine. Virology 369: $153-167$.

Lasaro MO, Ertl HC. 2009. New insights on adenovirus as vaccine vectors. Mol Ther 17: 1333-1339.

Leslie AJ, Pfafferott KJ, Chetty P, Draenert R, Addo MM, Feeney M, Tang Y, Holmes EC, Allen T, Prado JG, et al. 2004. HIV evolution: CTL escape mutation and reversion after transmission. Nat Med 10: 282-289.

Li Q, Duan L, Estes JD, Ma ZM, Rourke T, Wang Y, Reilly C, Carlis J, Miller CJ, Haase AT. 2005. Peak SIV replication in resting memory $\mathrm{CD} 4^{+} \mathrm{T}$ cells depletes gut lamina propria $\mathrm{CD}^{+}$T cells. Nature 434: 1148-1152.

Li Q, Skinner PJ, Ha SJ, Duan L, Mattila TL, Hage A, White C, Barber DL, O’Mara L, Southern PJ, et al. 2009. Visualizing antigen-specific and infected cells in situ predicts outcomes in early viral infection. Science 323: $1726-$ 1729.

Li H, Bar KJ, Wang S, Decker JM, Chen Y, Sun C, SalazarGonzalez JF, Salazar MG, Learn GH, Morgan CJ, et al. 2010. High multiplicity infection by HIV-1 in men who have sex with men. PLoS Pathog 6: e1000890.

Lichterfeld M, Yu XG, Cohen D, Addo MM, Malenfant J, Perkins B, Pae E, Johnston MN, Strick D, Allen TM, et al. 2004. HIV-1 Nef is preferentially recognized by CD8 $\mathrm{T}$ cells in primary HIV-1 infection despite a relatively high degree of genetic diversity. AIDS 18: 13831392.

Liu J, O’Brien KL, Lynch DM, Simmons NL, La Porte A, Riggs AM, Abbink P, Coffey RT, Grandpre LE, Seaman MS, et al. 2009. Immune control of an SIV challenge by a T-cell-based vaccine in rhesus monkeys. Nature 457: $87-91$.

Luxembourg A, Evans CF, Hannaman D. 2007. Electroporation-based DNA immunisation: Translation to the clinic. Expert Opin Biol Ther 7: 1647-1664.

Maness NJ, Walsh AD, Piaskowski SM, Furlott J, Kolar HL, Bean AT, Wilson NA, Watkins DI. 2010a. CD8 ${ }^{+} \mathrm{T}$ cell recognition of cryptic epitopes is a ubiquitous feature of AIDS virus infection. J Virol 84: 11569-11574.

Maness NJ, Wilson NA, Reed JS, Piaskowski SM, Sacha JB, Walsh AD, Thoryk E, Heidecker GJ, Citron MP, Liang $\mathrm{X}$, et al. 2010b. Robust, vaccine-induced $\mathrm{CD}^{+}{ }^{+} \mathrm{T}$ lymphocyte response against an out-of-frame epitope. $J$ Immunol 184: 67-72.

Martinez-Picado J, Prado JG, Fry EE, Pfafferott K, Leslie A, Chetty S, Thobakgale C, Honeyborne I, Crawford H, Matthews P, et al. 2006. Fitness cost of escape mutations in p24 Gag in association with control of human immunodeficiency virus type 1. J Virol 80: 3617-3623.

Mattapallil JJ, Douek DC, Hill B, Nishimura Y, Martin M, Roederer M. 2005. Massive infection and loss of memory $\mathrm{CD} 4^{+} \mathrm{T}$ cells in multiple tissues during acute SIV infection. Nature 434: 1093-1097.

McElrath MJ, De Rosa SC, Moodie Z, Dubey S, Kierstead L, Janes H, Defawe OD, Carter DK, Hural J, Akondy R, et al. 2008. HIV-1 vaccine-induced immunity in the test-ofconcept Step Study: A case-cohort analysis. Lancet 372: 1894-1905.
Mehandru S, Poles MA, Tenner-Racz K, Horowitz A, Hurley A, Hogan C, Boden D, Racz P, Markowitz M. 2004. Primary HIV-1 infection is associated with preferential depletion of $\mathrm{CD}^{+} \mathrm{T}$ lymphocytes from effector sites in the gastrointestinal tract. J Exp Med 200: 761-770.

Migueles SA, Sabbaghian MS, Shupert WL, Bettinotti MP, Marincola FM, Martino L, Hallahan CW, Selig SM, Schwartz D, Sullivan J, et al. 2000. HLA B*5701 is highly associated with restriction of virus replication in a subgroup of HIV-infected long term nonprogressors. Proc Natl Acad Sci 97: 2709-2714.

Migueles SA, Osborne CM, Royce C, Compton AA, Joshi RP, Weeks KA, Rood JE, Berkley AM, Sacha JB, Cogliano-Shutta NA, et al. 2008. Lytic granule loading of $\mathrm{CD}^{+} \mathrm{T}$ cells is required for HIV-infected cell elimination associated with immune control. Immunity 29: 1009-1021.

Moniuszko M, Bogdan D, Pal R, Venzon D, Stevceva L, Nacsa J, Tryniszewska E, Edghill-Smith Y, Wolinsky SM, Franchini G. 2005. Correlation between viral RNA levels but not immune responses in plasma and tissues of macaques with long-standing SIVmac251 infection. Virology 333: 159-168.

Mullins JI, Nickle DC, Heath L, Rodrigo AG, Learn GH. 2004. Immunogen sequence: The fourth tier of AIDS vaccine design. Expert Rev Vaccines 3(4 Suppl): S151-S159.

Nchinda G, Amadu D, Trumpfheller C, Mizenina O, Uberla K, Steinman RM. 2010. Dendritic cell targeted HIV gag protein vaccine provides help to a DNAvaccine including mobilization of protective CD8 ${ }^{+}$T cells. Proc Natl Acad Sci 107: 4281-4286.

Nickle DC, Jensen MA, Gottlieb GS, Shriner D, Learn GH, Rodrigo AG, Mullins JI. 2003. Consensus and ancestral state HIV vaccines. Science 299: 1515-1518.

Ogg GS, Jin X, Bonhoeffer S, Dunbar PR, Nowak MA, Monard S, Segal JP, Cao Y, Rowland-Jones SL, Cerundolo V, et al. 1998. Quantitation of HIV-1-specific cytotoxic T lymphocytes and plasma load of viral RNA. Science 279: 2103-2106.

Pal R, Venzon D, Santra S, Kalyanaraman VS, Montefiori DC, Hocker L, Hudacik L, Rose N, Nacsa J, Edghill-Smith Y, et al. 2006. Systemic immunization with an ALVACHIV-1/protein boost vaccine strategy protects rhesus macaques from $\mathrm{CD} 4{ }^{+} \mathrm{T}$-cell loss and reduces both systemic and mucosal simian-human immunodeficiency virus SHIVKU2 RNA levels. J Virol 80: 3732-3742.

Pantaleo G, Esteban M, Jacobs B, Tartaglia J. 2010. Poxvirus vector-based HIV vaccines. Curr Opin HIVAIDS 5: 391396.

Peng B, Wang LR, Gomez-Roman VR, Davis-Warren A, Montefiori DC, Kalyanaraman VS, Venzon D, Zhao J, Kan E, Rowell TJ, et al. 2005. Replicating rather than nonreplicating adenovirus-human immunodeficiency virus recombinant vaccines are better at eliciting potent cellular immunity and priming high-titer antibodies. J Virol 79: 10200-10209.

Petrovas C, Casazza JP, Brenchley JM, Price DA, Gostick E, Adams WC, Precopio ML, Schacker T, Roederer M, Douek DC, et al. 2006. PD-1 is a regulator of virusspecific $\mathrm{CD}^{+} \mathrm{T}$ cell survival in HIV infection. $J$ Exp Med 203: 2281-2292. 
R.A. Koup and D.C. Douek

Picard O, Lebas J, Imbert JC, Bigel P, Zagury D. 1991. Complication of intramuscular/subcutaneous immune therapy in severely immune-compromised individuals. J Acquir Immune Defic Syndr 4: 641-643.

Pillai VB, Hellerstein M, Yu T, Amara RR, Robinson HL. 2008. Comparative studies on in vitro expression and in vivo immunogenicity of supercoiled and open circular forms of plasmid DNA vaccines. Vaccine 26: 1136-1141.

Price DA, Asher TE, Wilson NA, Nason MC, Brenchley JM, Metzler IS, Venturi V, Gostick E, Chattopadhyay PK, Roederer M, et al. 2009. Public clonotype usage identifies protective Gag-specific $\mathrm{CD}^{+} \mathrm{T}$ cell responses in SIV infection. J Exp Med 206: 923-936.

Rerks-Ngarm S, Pitisuttithum P, Nitayaphan S, Kaewkungwal J, Chiu J, Paris R, Premsri N, Namwat C, de Souza M, Adams E, et al. 2009. Vaccination with ALVAC and AIDSVAX to prevent HIV-1 infection in Thailand. N Engl J Med 361: 2209-2220.

Robert-Guroff M. 2007. Replicating and non-replicating viral vectors for vaccine development. Curr Opin Biotechnol 18: 546-556.

Rolland M, Heckerman D, Deng W, Rousseau CM, Coovadia H, Bishop K, Goulder PJ, Walker BD, Brander C, Mullins JI. 2008. Broad and Gag-biased HIV-1 epitope repertoires are associated with lower viral loads. PLoS One 3: e1424.

Rosenberg ES, Billingsley JM, Caliendo AM, Boswell SL, Sax PE, Kalams SA, Walker BD. 1997. Vigorous HIV-1specific $\mathrm{CD}^{+} \mathrm{T}$ cell responses associated with control of viremia. Science 278: 1447-1450.

Santra S, Liao HX, Zhang R, Muldoon M, Watson S, Fischer W, Theiler J, Szinger J, Balachandran H, Buzby A, et al. 2010. Mosaic vaccines elicit $\mathrm{CD}^{+}{ }^{+} \mathrm{T}$ lymphocyte responses that confer enhanced immune coverage of diverse HIV strains in monkeys. Nat Med 16: 324-328.

Schmitz JE, Kuroda MJ, Santra S, Sasseville VG, Simon MA, Lifton MA, Racz P, Tenner-Racz K, Dalesandro M, Scallon BJ, et al. 1999. Control of viremia in simian immunodeficiency virus infection by $\mathrm{CD}^{+}$lymphocytes. Science 283: $857-860$.

Schneidewind A, Brockman MA, Yang R, Adam RI, Li B, Le Gall S, Rinaldo CR, Craggs SL, Allgaier RL, Power KA, et al. 2007. Escape from the dominant HLA-B27restricted cytotoxic T-lymphocyte response in Gag is associated with a dramatic reduction in human immunodeficiency virus type 1 replication. J Virol 81: 12382 12393.

Seaman MS, Xu L, Beaudry K, Martin KL, Beddall MH, Miura A, Sambor A, Chakrabarti BK, Huang Y, Bailer R, et al. 2005. Multiclade human immunodeficiency virus type 1 envelope immunogens elicit broad cellular and humoral immunity in rhesus monkeys. J Virol 79: 2956-2963.

Shiver JW, Fu TM, Chen L, Casimiro DR, Davies ME, Evans RK, Zhang ZQ, Simon AJ, Trigona WL, Dubey SA, et al. 2002. Replication-incompetent adenoviral vaccine vector elicits effective anti-immunodeficiency-virus immunity. Nature 415: 331-335.

Simons BC, Vancompernolle SE, Smith RM, Wei J, Barnett L, Lorey SL, Meyer-Olson D, Kalams SA. 2008. Despite biased TRBV gene usage against a dominant HLA B57 restricted epitope, TCR diversity can provide recognition of circulating epitope variants. J Immunol 181: 51375146.

Smith CL, Mirza F, Pasquetto V, Tscharke DC, Palmowski MJ, Dunbar PR, Sette A, Harris AL, Cerundolo V. 2005. Immunodominance of poxviral-specific CTL in a human trial of recombinant-modified vaccinia Ankara. J Immunol 175: 8431-8437.

Spentzou A, Bergin P, Gill D, Cheeseman H, Ashraf A, Kaltsidis H, Cashin-Cox M, Anjarwalla I, Steel A, Higgs C, et al. 2010. Viral inhibition assay: A CD8 T cell neutralization assay for use in clinical trials of HIV-1 vaccine candidates. J Infect Dis 201: 720-729.

Steinman RM. 2008. Dendritic cells in vivo: A key target for a new vaccine science. Immunity 29: 319-324.

Tewari K, Flynn BJ, Boscardin SB, Kastenmueller K, Salazar AM, Anderson CA, Soundarapandian V, Ahumada A, Keler T, Hoffman SL, et al. 2010. Poly(I:C) is an effective adjuvant for antibody and multi-functional $\mathrm{CD} 4^{+} \mathrm{T}$ cell responses to Plasmodium falciparum circumsporozoite protein (CSP) and alphaDEC-CSP in non human primates. Vaccine 28: 7256-7266.

Trautmann L, Janbazian L, Chomont N, Said EA, Gimmig S, Bessette B, Boulassel MR, Delwart E, Sepulveda H, Balderas RS, et al. 2006. Upregulation of PD-1 expression on HIV-specific $\mathrm{CD}^{+}{ }^{+} \mathrm{T}$ cells leads to reversible immune dysfunction. Nat Med 12: 1198-1202.

Tritel M, Stoddard AM, Flynn BJ, Darrah PA, Wu CY, Wille U, Shah JA, Huang Y, Xu L, Betts MR, et al. 2003. Primeboost vaccination with HIV-1 Gag protein and cytosine phosphate guanosine oligodeoxynucleotide, followed by adenovirus, induces sustained and robust humoral and cellular immune responses. J Immunol 171: 2538 2547.

Turnbull EL, Lopes AR, Jones NA, Cornforth D, Newton P, Aldam D, Pellegrino P, Turner J, Williams I, Wilson CM, et al. 2006. HIV-1 epitope-specific CD $8^{+} \mathrm{T}$ cell responses strongly associated with delayed disease progression cross-recognize epitope variants efficiently. J Immunol 176: $6130-6146$.

Ueno H, Klechevsky E, Schmitt N, Ni L, Flamar AL, Zurawski S, Zurawski G, Palucka K, Banchereau J, Oh S. 2011. Targeting human dendritic cell subsets for improved vaccines. Semin Immunol 23: 21-27.

Ulmer JB, Donnelly JJ, Parker SE, Rhodes GH, Felgner PL, Dwarki VJ, Gromkowski SH, Deck RR, DeWitt CM, Friedman A, et al. 1993. Heterologous protection against influenza by injection of DNA encoding a viral protein. Science 259: 1745-1749.

Wang YE, Li B, Carlson JM, Streeck H, Gladden AD, Goodman R, Schneidewind A, Power KA, Toth I, Frahm N, et al. 2009. Protective HLA class I alleles that restrict acute-phase $\mathrm{CD} 8^{+}$T-cell responses are associated with viral escape mutations located in highly conserved regions of human immunodeficiency virus type 1. J Virol 83: $1845-1855$.

Wolff JA, Malone RW, Williams P, Chong W, Acsadi G, Jani A, Felgner PL. 1990. Direct gene transfer into mouse muscle in vivo. Science 247: 1465-1468.

Yang OO, Kalams SA, Rosenzweig M, Trocha A, Jones N, Koziel M, Walker BD, Johnson RP. 1996. Efficient lysis of human immunodeficiency virus type 1-infected cells by cytotoxic T lymphocytes. J Virol 70: 5799-5806. 
Vaccine Design for CD8 T Lymphocyte Responses

Yang OO, Kalams SA, Trocha A, Cao H, Luster A, Johnson RP, Walker BD. 1997. Suppression of human immunodeficiency virus type 1 replication by $\mathrm{CD} 8^{+}$cells: Evidence for HLA class I-restricted triggering of cytolytic and noncytolytic mechanisms. J Virol 71: 3120-3128.

Zagury D. 1991. Anti-HIV cellular immunotherapy in AIDS. Lancet 338: 694-695.

Zagury D, Bernard J, Cheynier R, Desportes I, Leonard R, Fouchard M, Reveil B, Ittele D, Lurhuma Z, Mbayo K, et al. 1988. A group specific anamnestic immune reaction against HIV-1 induced by a candidate vaccine against AIDS. Nature 332: 728-731.

Zuniga R, Lucchetti A, Galvan P, Sanchez S, Sanchez C, Hernandez A, Sanchez H, Frahm N, Linde CH, Hewitt HS, et al. 2006. Relative dominance of Gag p24-specific cytotoxic $\mathrm{T}$ lymphocytes is associated with human immunodeficiency virus control. J Virol 80: $3122-$ 3125. 


\section{$\&_{\mathrm{CSH}}^{\infty} \&$ Cold Spring Harbor

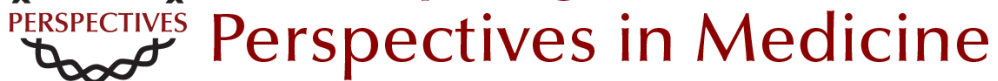

\section{Vaccine Design for CD8 T Lymphocyte Responses}

Richard A. Koup and Daniel C. Douek

Cold Spring Harb Perspect Med 2011; doi: 10.1101/cshperspect.a007252

\section{Subject Collection HIV}

HIV Pathogenesis: Dynamics and Genetics of

Viral Populations and Infected Cells John Coffin and Ronald Swanstrom

Human Immunodeficiency Virus Vaccine Trials Robert J. O'Connell, Jerome H. Kim, Lawrence Corey, et al.

HIV Transmission George M. Shaw and Eric Hunter

Novel Cell and Gene Therapies for HIV James A. Hoxie and Carl H. June

\section{Behavioral and Biomedical Combination}

Strategies for HIV Prevention Linda-Gail Bekker, Chris Beyrer and Thomas C. Quinn

HIV-1 Assembly, Budding, and Maturation Wesley I. Sundquist and Hans-Georg Kräusslich

HIV-1 Assembly, Budding, and Maturation Wesley I. Sundquist and Hans-Georg Kräusslich

Lessons in Nonhuman Primate Models for AIDS Vaccine Research: From Minefields to Milestones Jeffrey D. Lifson and Nancy L. Haigwood
HIV-1 Pathogenesis: The Virus Ronald Swanstrom and John Coffin

The T-Cell Response to HIV Bruce Walker and Andrew McMichael

HIV-1 Reverse Transcription Wei-Shau Hu and Stephen H. Hughes

HIV Pathogenesis: The Host A.A. Lackner, Michael M. Lederman and Benigno Rodriguez

HIV: Cell Binding and Entry Craig B. Wilen, John C. Tilton and Robert W. Doms

Innate Immune Control of HIV Mary Carrington and Galit Alter

HIV DNA Integration Robert Craigie and Frederic D. Bushman

HIV-1-Related Central Nervous System Disease: Current Issues in Pathogenesis, Diagnosis, and Treatment

Serena Spudich and Francisco González-Scarano

For additional articles in this collection, see http://perspectivesinmedicine.cshlp.org/cgi/collection/ 